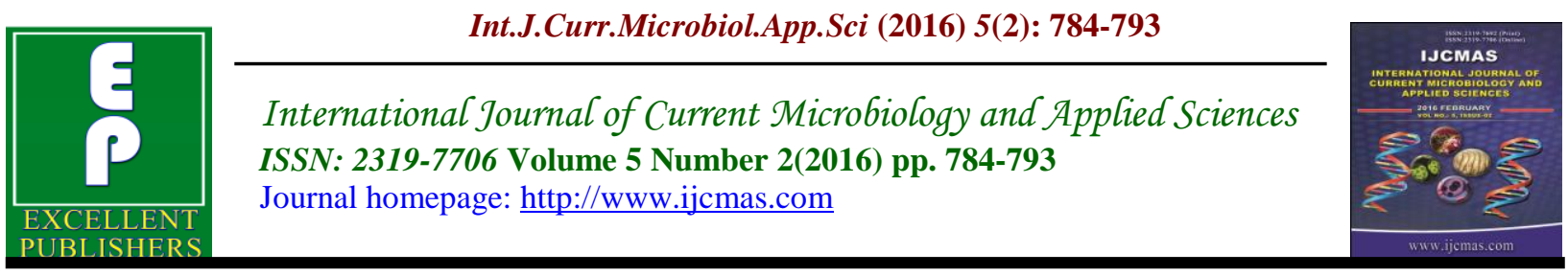

Original Research Article

doi: http://dx.doi.org/10.20546/ijcmas.2016.502.089

\title{
Analysis of forest vegetation in Pithoragarh Kumaun Himalayas, Uttrakhand, India
}

\author{
Anjali Bhatt* and N.S. Bankoti \\ Department of Botany, Kumaun University, LSM College, Pithoragarh, Uttarakhand, India \\ *Corresponding author
}

\begin{abstract}
A B S T R A C T
Keywords

Diversity, distribution pattern,

Concentration of

Dominance,

IVI and Species

Richness.

Article Info

Accepted:

28 January 2016

Available Online:

10, February 2016

This study deals with the floristic composition and distribution pattern of the different tree species with reference to density, IVI, diversity index and the structural characteristics of tree communities in a moist temperate forest. The study was conducted in Pithoragarh of Kumaun Himalayas along an elevation gradient of 1554-1969 masl. The study area is dominated by Quercus floribunda in tree layers and is regarded as the climax species. For the study, the area is divided into three compartments. Phytosociological characteristics differ among different tree species. The compartment $\mathrm{A}$ has the highest species richness and also exhibits the highest species diversity of 2.84. The tree density has been found to be highest in compartment B of 24.45 trees $/ \mathrm{m}^{2}$. The concentration of dominance varied between $0.154, .214$ and 0.191 . The highest has been recorded in the compartment B. I.V.I was significantly higher for Quercus floribunda and Q. leucotrichophora than any other species in tree; sapling stratum was dominating in different compartment of forest.
\end{abstract}

\section{Introduction}

A special place in mountain ecosystems of the world is occupies by Kumaun Himalayan region. The Himalayan forest vegetation ranges from tropical dry deciduous forest in the foothills to alpine meadow above timberline (Singh and Singh,1992) A highly diverse, compositional pattern of forest is characteristic of this region (Singh and Singh1984). Varied range of habitats is provided by these forests for the growth of extraordinarily rich and diversified assemblages of flora. Various workers have described structural character of Himalayan forests.
Species composition of major forest types of central Himalaya have been described by Ralhan et al (1982), Saxena and Singh (1984), Singh and Singh (1987), Singh and Singh (1992) have summarized the information on the structure and function of the Himalayan forest ecosystem. The forests sustainability largely depends on the regeneration potential of the various species composition in Kumaun forests. Population structure of a species in a forest conveys its regeneration behaviour (Saxena and Singh, 1984). Thus, the different tree species regeneration behaviour is characterized by 
their population structure which largely depends upon the adequate number of their seedling, sapling and different girth classes. The present study was carried out to analyses the forest vegetation (woody components) in relation to an elevation gradient and aspects and impact assessment of biotic disturbances on vegetation structure, composition, diversity, species richness and regeneration potential in Badoli forests of Pithoragarh.

\section{Materials and Methods}

\section{Study Site}

The study site "Badoli forest" is located at a distance of app. $10 \mathrm{~km}$ from the main town of Pithoragarh, Pithoragarh district, in Kumaun region of central Himalayas. Of the total forest area of Pithoragarh district, which are about 83,710.3 ha, of which 12.437 hectare is covered by Badoli forest. The forest extends from the base of Badoli village (1554m altitude) to the top of the $(1969 \mathrm{~m})$ altitude. The Badoli forest is

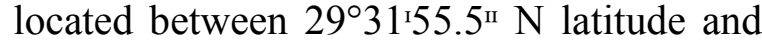

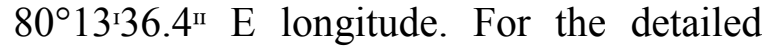
study of tree layer composition and other vegetation parameters, the area was divided into three compartments with varying degree of disturbance were selected in this forest. These three sites are located at different altitudinal range and dominated by $Q$. leucotrichophora and Q. floribunda trees. There is a temple of Devi and lord Shiva at the top of hill, which is centre of religious purpose of villagers.

\section{Climate}

The climate of studied forest is of temperate type, characterised by warm and short summer season, moist and wet rainy season and pronounced severe winter season. The soil is residual to fairly deep being derived from dolomite limestone, sand stones and silt. The maximum monthly rainfall of $530 \mathrm{~mm}$. was noticed in the month of June. While the wettest month of the year were June, July.August and September this together accounted for a total precipitation of $640.4 \mathrm{~mm}$ in the year $(43.2 \%)$ of the total precipitation.

The humidity is highest in the rainy season. The average value of humidity varied from 38 to $84 \%$ during the study period, while the average humidity was 63.33. The lowest humidity was recorded in April with the higher humidity being in the month of September.

\section{Vegetation Analysis}

The sampling was done at three different compartments of Badoli forest.Species richness wasdetermined as the number of species per unitarea (Whittaker, 1965). The entire forest wasdivided into three compartments, A, B, C.The tree, sapling and seedling were analysedwithin the same quadrate. The size and number of quadrats were determined by using the species-area curve (Mishra, 1968) and the running mean method. (Kershaw, 1973). For analysis of trees and saplings 20, 10×10 m,quadrates were laid. (Curtis and McIntosh, 1950; Phillips, 1959). In the forest regeneration wassampled atmature tree, sapling and seedling level. The plant havingcircumference at breast height (cbh) was $1.37 \mathrm{~m}$ and above (Knight, 1963) and thosehaving cbh lower than $30 \mathrm{cms}$ but not lessthan $10 \mathrm{cms}$ were considered as tree andsapling, respectively. Individual whose cbhwas below $10 \mathrm{cms}$ were considered asseedling.

The vegetation data for quantitative analyses of abundance, density, frequency, was according to Curtis andMcIntosh (1956). $\mathrm{A} / \mathrm{F}$ ratio according to Whitford (1949) According toCurtis and Cottom (1956), the 
ratio of abundance to frequency below 0.025 indicates regular distribution, between 0.025 and 0.050 indicates random distribution and when exceeds 0.05 , indicates contagious distribution. The relative frequency, relative density, and relative basal area were determined according to Phillips (1959). Important value index (IVI) for the various species represents the sum of relative frequency, relative basal area and relative density (Curtis and McIntosh, 1951).

Species diversity was calculated using Shannon wiener information index (Shannon and Weaver, 1963) as:

\section{$\mathrm{H}=-\Sigma(\mathrm{Ni} / \mathrm{N}) \log 2(\mathrm{Ni} / \mathrm{N})$}

$\mathrm{Ni}=$ Total number of individuals of a species, $\mathrm{N}=$ Total number of individuals of all species.

Concentration of Dominance (CD) was measured by Simpson's index (Simpson 1949) as:

\section{S 2}

$\mathrm{C}=\boldsymbol{\Sigma}(\mathrm{Ni} / \mathrm{N})$

\section{$\mathbf{i}=\mathbf{1}$}

Where, Ni is the total number of individuals of species and $\mathrm{N}$ is the total number of individuals of all species

\section{Results and Discussion}

\section{Phytosociology}

Phytosociological data for the study sites are summarized in table's below. A total of 21 trees were recorded from different three compartments of the present study site. The most dominant tree species was Quercus floribunda (IVI-85.63) in comp. Band comp. $C$ (IVI-83.49) and is followed by the dominance of Pinus roxburghii (IVI-60.85) in comp. A.

At compartment A: Pinus roxburghii exhibits absolute dominance in the terms of density (3 trees $/ 100 \mathrm{~m}^{2}$ ), total basal cover $\left(1532.96 \mathrm{~cm}^{2} / 100 \mathrm{~m}^{2}\right)$ and IVI (60.85). The co-dominant species in this forest is Quercus leucotrichophora having density of (2.95trees $/ 100 \mathrm{~m}^{2}$ ) and (IVI 60.07), M. esculenta IVI of 40.84.S. insigne Benth ext.is the least important of all the species with a density of .05 trees $/ 100 \mathrm{~m}^{2}$ and an IVI of 1.59.In sapling stratum Quercus leucotrichophora is followed by Pinus roxburghii in dominance, while in seedling stratum Pinus roxburghii is dominant and Quercus leucotrichophorais co - dominant species.

At compartment B: Quercus floribundais dominant species in terms of density $\left(8.95\right.$ trees $\left./ 100 \mathrm{~m}^{2}\right)$. The mean basal area and the IVI are 509.14 and 85.65respectively. The total basal cover (Dominance) was $4556.88 \mathrm{~cm}^{2} / 100 \mathrm{~m}^{2}$. The co-dominant species is Quercus leucotrichophora with a density of 6.55 trees $/ 100 \mathrm{~m}^{2}$ and IVI 65.46 (Table 2). Quercus floribunda exhibits absolute dominance in the terms of density, total basal cover and IVI.The other important trees in association are $P$. roxburghii, Cedrus deodara and $M$. esculenta with their respective densities of $3.35,1.15$ and 1.55 trees $/ 100 \mathrm{~m}^{2}$. In order of their importance the IVI's are 35.0, 21.16, and 21.70 respectively. The mean basal area is highest, $1145.59 \mathrm{~m}^{2} /$ tree in Cedrus deodara and lowest, $215.12 \mathrm{~m}^{2} /$ tree, inE. officinalis. Sapium. insigne Benth and $P$. cerasoides are the least important species with the dominance of $41.54 \mathrm{~cm}^{2} / 100 \mathrm{~m}^{2}$ and $82.48 \mathrm{~cm}^{2} / 100 \mathrm{~m}^{2}$ respectively In sapling stratum Quercus floribunda isfollowed by Pinus roxburghii in dominance, while in seedling stratum Quercus floribundais dominant species. 
At compartment $C: Q$. floribundais a dominant tree species in terms of density $\left(5.85\right.$ trees $\left./ 100 \mathrm{~m}^{2}\right)$. The mean basal area is 423.95 tree $/ \mathrm{m}^{2}$ and the IVI 83.49. The dominance for this species is $2480.08 \mathrm{~cm}^{2} /$ $100 \mathrm{~m}^{2}$ the co-dominant species is Quercus leucotrichophora with a density of 4.60 trees/ 100 $\mathrm{m}^{2}$ and IVI 66.06 (Table 4). The other important trees are $M$. esculenta with a density of 2.15 trees/ $\mathrm{m}^{2}$ and IVI 38.35,E. officinalis (2.45 trees/ $\mathrm{m}^{2}$ and 31.55) and Rhododendron arboreum $\left(1.85\right.$ trees/ $\mathrm{m}^{2}$ and 28.84). C.deodara and F. ausiculata are poorly distributed and occupy the density of .35 and .30 trees $/ \mathrm{m}^{2}$. In both sapling and seedling stratum Quercus floribunda is followed by Quercus leucotrichophora in dominance, while in seedlingstratum Quercusfloribundais dominant species

\section{Distribution Pattern}

The analysis of distribution pattern of various species of tree layer, high percentage of tree species exhibited contagious pattern of distribution. Random pattern of distribution was found in sizable proportion and regular pattern was very rare. For entire tree layers of different compartment of Badoli forest,contagious pattern is contributes $85.33 \%$, random pattern $11 \%$ and regular pattern $3.66 \%$ in distribution.
For sapling, the entire Badoli forest showed about $82.33 \%$ cases contagious and over $7.33 \%$ random and nearly $2.33 \%$ cases regular pattern of distribution. Both in seedling layer of different compartment showed the same pattern of distribution with higher percentage of contagious pattern followed by random distribution andregular pattern of distribution contributes very low in distribution pattern. The general pattern of distribution in different layers of vegetation in all three compartment of forest is contagious $>$ random $>$ regular. The distribution pattern of adult trees was generally corresponding more or less with the distribution pattern of sapling or seedling of the same species.

Phytosociological characteristics differ among different habitat types and among tree species. In this study species richness in compartment - A has been found to be 19 , Pinus roxburghii was found to be dominant species in tree, sapling and seedling stratum with density and IVI of $3,2,1.65$ trees/ $100 \mathrm{~m}^{2}$ and $60.85,62.01,59.54$ respectively. Similarly in the compartment B, species richness has been found to be 15 , the highest mean basal cover is exhibited by Quercus floribunda $\left(534.92 \mathrm{~cm}^{2} /\right.$ tree $)$ for tree, Pinus roxburghii $\left(23 \mathrm{~cm}^{2} /\right.$ tree, $2.98 \mathrm{~cm}^{2} /$ tree $)$ for sapling and seedling respectively.

Table.1 Characteristics of the Study Sites

\begin{tabular}{cllll}
\hline COMPARTMENTS & \multicolumn{1}{c}{ ASPECTS } & ALTITUDE(m) & Do. TREE SP. \\
\hline 1. & A & East-South & $1500-1859 \mathrm{~m}$ & Pinus roxburghii. \\
2. & B & East - North. & $1550-1800 \mathrm{~m}$ & Quercus floribunda \\
3. & C & West - North. & $1500-1900 \mathrm{~m}$ & Quercus floribunda \\
\hline
\end{tabular}


Table.2 Phytosociological Attributes of Plant Species in Site -A of Badoli Forest

\begin{tabular}{|c|c|c|c|c|c|c|c|}
\hline Species & $\begin{array}{l}D \text { trees } \\
/ 100 m^{2}\end{array}$ & $\begin{array}{l}\text { Frequency } \\
(\%)\end{array}$ & $\begin{array}{l}\text { Abunda } \\
\text { nce }\end{array}$ & $\mathbf{A} / \mathbf{F}$ & $\begin{array}{c}\text { MBA } \\
\left(\mathrm{cm}^{2} \text { trees }^{-1}\right)\end{array}$ & $\begin{array}{l}\text { TBA (cm2 } \\
\left./ 100 \mathbf{m}^{2}\right)\end{array}$ & IVI \\
\hline \multicolumn{8}{|l|}{ TREES } \\
\hline Aesculus. indica & .35 & 25 & 1.4 & .056 & 561.33 & 196.46 & 10.82 \\
\hline Bauhinia. variegate & .15 & 15 & 1 & .066 & 357.12 & 53.56 & 5.03 \\
\hline Biota. orientalis & .30 & 25 & 1.2 & .048 & 521.96 & 156.59 & 9.82 \\
\hline Callistemone. citrinus & .20 & 10 & 2 & .200 & 378.76 & 99.30 & 5.1 \\
\hline Cedrus. deodara & .35 & 20 & 1.75 & .087 & 962.61 & 336.91 & 12.00 \\
\hline Celtis. australis & .25 & 20 & 1.25 & .063 & 1145.6 & 286.39 & 10.46 \\
\hline Cryptotepis. buchanani & .15 & 10 & 1.5 & .150 & 206.92 & 31.04 & 3.66 \\
\hline Ficus. palmata & .30 & 20 & 1.5 & .075 & 447.49 & 134.25 & 8.44 \\
\hline Ficus. ausiculata & .20 & 20 & 1 & .05 & 412.41 & 82.48 & 6.88 \\
\hline Regia. virgata & 1 & 30 & 3.33 & .11 & 459.51 & 459.51 & 20.86 \\
\hline Juglans. regior & .1 & 10 & 1 & .1 & 795.54 & 79.55 & 4.04 \\
\hline Myrica. esculenta & 2.55 & 50 & 5.1 & .102 & 286.39 & 730.31 & 40.84 \\
\hline Pinus. roxburghii & 3.00 & 70 & 4.28 & .061 & 471.68 & 1532.96 & 60.85 \\
\hline Prunus. cerasoides & .30 & 20 & 1.5 & .075 & 231.98 & 69.59 & 7.43 \\
\hline Pyrus.pashia & .35 & 30 & 1.16 & .038 & 378.76 & 132.57 & 10.83 \\
\hline Quercus. floribunda & .45 & 20 & 2.25 & .112 & 315.75 & 142.08 & 9.69 \\
\hline Q. leucotrichophora & 2.95 & 70 & 4.21 & .060 & 509.15 & 1501.99 & 60.07 \\
\hline Sapindus. mukorossi & .30 & 20 & 1.5 & .075 & 1107.7 & 332.32 & 11.56 \\
\hline Sapium. insigne & .05 & 5 & 1 & .20 & 240.65 & 12.03 & 1.59 \\
\hline TOTAL & 13.3 & 490 & & & & 6364.39 & 300 \\
\hline \multicolumn{8}{|l|}{ SAPLING- } \\
\hline A. indica & .20 & 15 & 1.33 & .088 & 22.99 & 4.60 & 7.70 \\
\hline B. variegate & .30 & 10 & 3 & .30 & 24.36 & 7.30 & 8.43 \\
\hline B. orientalis & .10 & 10 & 1 & .10 & 35.08 & 3.51 & 4.88 \\
\hline C. citrinus & .30 & 15 & 2 & .133 & 11.74 & 3.44 & 8.49 \\
\hline C. deodara & .15 & 10 & 1.5 & .15 & 71.60 & 10.73 & 7.21 \\
\hline F. palmate & .15 & 15 & 1 & .15 & 17.90 & 2.68 & 6.50 \\
\hline J. regior & .30 & 25 & 1.2 & .048 & 66.90 & 20.07 & 16.46 \\
\hline M. esculenta & 1.25 & 50 & 2.5 & .05 & 38.50 & 48.13 & 43.08 \\
\hline P. roxburghii & 2 & 70 & 2.85 & .040 & 31.82 & 63.64 & 62.01 \\
\hline P. cerasoides & .15 & 10 & 1.5 & .15 & 19.86 & 2.87 & 5.26 \\
\hline P. pashia & .40 & 20 & 2 & .10 & 25.77 & 10.31 & 13.17 \\
\hline Q. floribunda & 1.05 & 35 & 3 & .08 & 30.16 & 30.15 & 31.05 \\
\hline Q. leucotrichophora & 1.8 & 80 & 2.25 & .028 & 42.08 & 75.75 & 66.20 \\
\hline S. mukorossi & .45 & 20 & 2.25 & .113 & 57.99 & 26.09 & 18.86 \\
\hline TOTAL & 8.60 & 385 & & & & 309.27 & 300 \\
\hline \multicolumn{8}{|l|}{ SEEDLING } \\
\hline A. indica & .20 & 15 & 1.33 & .088 & 3.90 & .78 & 9.39 \\
\hline B. variegate & .60 & 35 & 1.71 & .048 & 5.09 & 3.05 & 28.37 \\
\hline B. orientalis & .05 & 5 & 1 & .20 & 1.91 & 0.10 & 2.31 \\
\hline C. australis & .25 & 5 & 4 & .25 & 7.65 & 1.91 & 11.84 \\
\hline C. citrinus & .30 & 15 & 2 & .133 & 2.15 & 0.65 & 10.25 \\
\hline C. deodara & .15 & 10 & 1.5 & .15 & 8.28 & 1.24 & 9.20 \\
\hline F. palmate & .55 & 30 & 1.83 & .061 & 2.07 & 1.14 & 19.23 \\
\hline J. regior & .25 & 20 & 1.25 & .062 & 8.61 & 2.15 & 16.50 \\
\hline M. esculenta & 1.5 & 80 & 1.8 & .06 & 3.36 & 5.04 & 59.30 \\
\hline P. roxburghii & 1.65 & 80 & 2.06 & .025 & 2.77 & 4.57 & 59.54 \\
\hline P. cerasoides & .05 & 5 & 1 & .20 & 4.01 & 0.20 & 2.69 \\
\hline P. pashia & .20 & 15 & 1.33 & .088 & 1.61 & 0.32 & 7.66 \\
\hline Q. floribunda & .20 & 15 & 1.33 & .088 & 3.36 & 0.67 & 8.98 \\
\hline Q. leucotrichophora & 1.35 & 60 & 2.25 & .037 & 2.87 & 3.87 & 47.84 \\
\hline S. mukorossi & .10 & 10 & 1 & 0.1 & 7.96 & .80 & 6.87 \\
\hline TOTAL & 7.4 & 400 & & & & 26.49 & 300 \\
\hline
\end{tabular}


Table.3 Phytosociological Attribute of Plant Species in Site - B of Badoli Forest

\begin{tabular}{|c|c|c|c|c|c|c|c|}
\hline Species & D & $\mathbf{F}$ & $\mathbf{A}$ & $\mathbf{A} / \mathbf{F}$ & MBA & TBA & IVI \\
\hline \multicolumn{8}{|l|}{ TREES } \\
\hline C. deodara & 1.15 & 35 & 3.29 & .094 & 1145.59 & 1317.42 & 21.16 \\
\hline C. tamala & .35 & 20 & 1.75 & .080 & 748.53 & 261.98 & 7.27 \\
\hline E. officinalis & .65 & 40 & 1.62 & .040 & 215.12 & 139.82 & 11.50 \\
\hline F. palmate & .70 & 25 & 2.8 & .112 & 496.49 & 347.55 & 10.26 \\
\hline F. ausiculata & .40 & 20 & 2 & .10 & 447.47 & 178.99 & 6.85 \\
\hline J. regior & .45 & 15 & 3 & .20 & 658.79 & 296.46 & 6.91 \\
\hline M. esculenta & 1.55 & 55 & 2.8 & .05 & 412.41 & 639.24 & 21.7 \\
\hline P. roxburghii & 3.35 & 50 & 6.7 & .134 & 484.01 & 1621.43 & 35.02 \\
\hline P. cerasoides & .20 & 15 & 1.3 & .09 & 412.41 & 82.48 & 4.37 \\
\hline P. pashia & .40 & 15 & 2.7 & .18 & 521.96 & 208.78 & 6.08 \\
\hline Q. floribunda & 8.95 & 85 & 10.5 & .12 & 509.14 & 4556.88 & 85.63 \\
\hline Q. leucotrichophora & 6.55 & 70 & 9.36 & .13 & 534.92 & 3503.75 & 65.46 \\
\hline R. arboreum & .25 & 20 & 1.25 & .06 & 412.41 & 103.10 & 5.70 \\
\hline S. mukorossi & .35 & 25 & 1.4 & .06 & 717.98 & 251.29 & 8.18 \\
\hline S. insigne & .15 & 15 & 1 & .07 & 276.93 & 41.54 & 3.86 \\
\hline TOTAL & 25.45 & 505 & & & & 13550.7 & 300 \\
\hline \multicolumn{8}{|l|}{ SAPLING } \\
\hline C. deodara & .70 & 20 & 3.5 & .175 & 71.60 & 50.12 & 30.2 \\
\hline C. tamala & .30 & 10 & 3.0 & .300 & 62.37 & 18.71 & 12.38 \\
\hline E. officinalis & .70 & 25 & 2.8 & .112 & 11.07 & 7.75 & 16.75 \\
\hline F. palmate & .25 & 15 & 1.7 & .113 & 35.08 & 8.77 & 9.85 \\
\hline F. ausiculata & .25 & 15 & 1.7 & .113 & 17.90 & 4.47 & 11.24 \\
\hline J. regior & .30 & 15 & 2.0 & .133 & 62.37 & 18.71 & 13.83 \\
\hline M. esculenta & .80 & 30 & 2.7 & .090 & 15.59 & 12.47 & 20.84 \\
\hline P. roxburghii & 1.15 & 40 & 2.9 & .071 & 23.00 & 26.44 & 32.05 \\
\hline P. cerasoides & .20 & 10 & 2.0 & .200 & 31.82 & 6.36 & 7.07 \\
\hline P. pashia & .25 & 15 & 1.7 & .113 & 28.72 & 9.29 & 7.18 \\
\hline Q. floribunda & 3.8 & 80 & 12.7 & .158 & 20.37 & 77.39 & 87.29 \\
\hline Q. leucotrichophora & .90 & 35 & 2.57 & .073 & 25.78 & 23.19 & 27.03 \\
\hline R. arboreum & .35 & 15 & 2.3 & .150 & 15.59 & 5.45 & 9.65 \\
\hline S. mukorossi & .35 & 20 & 1.75 & .087 & 49.72 & 17.40 & 15.3 \\
\hline TOTAL & 10.3 & 345 & & & & 284.44 & 300. \\
\hline \multicolumn{8}{|l|}{ SEEDLING } \\
\hline C. deodara & .55 & 30 & 1.8 & .06 & 7.64 & 4.20 & 47.02 \\
\hline C. tamala & .25 & 10 & 2.5 & .25 & 6.30 & 1.58 & 18.07 \\
\hline E. officinalis & .50 & 20 & 2.5 & .12 & 0.97 & 0.49 & 21.39 \\
\hline F. palmate & .05 & 5 & 1.0 & .20 & 1.34 & 0.07 & 3.48 \\
\hline F. ausiculata & .35 & 20 & 1.7 & .08 & 2.15 & 0.75 & 19.67 \\
\hline J. regior & .15 & 10 & 1.5 & .15 & 5.61 & 0.84 & 11.87 \\
\hline M. esculenta & .20 & 15 & 1.3 & .090 & 2.57 & 0.59 & 13.59 \\
\hline P. roxburghii & .85 & 35 & 2.4 & .070 & 2.98 & 2.53 & 46.08 \\
\hline P. cerasoides & .10 & 10 & 1.0 & .100 & 2.68 & 0.27 & 7.67 \\
\hline P. pashia & .05 & 5 & 1.0 & 200 & 1.91 & 0.09 & 3.59 \\
\hline Q. floribunda & .85 & 40 & 2.12 & .050 & 2.86 & 2.43 & 47.64 \\
\hline Q. leucotrichophora & .55 & 35 & 1.6 & .040 & 4.47 & 2.46 & 39.46 \\
\hline$R$. arboreum & .10 & 5 & 2.0 & .400 & 1.79 & 0.18 & 5.13 \\
\hline S. mukorossi & .20 & 5 & 4.0 & .800 & 8.12 & 1.62 & 15.2 \\
\hline TOTAL & 4.75 & 245 & & & & 18.1 & 300 \\
\hline
\end{tabular}


Table.4 Phytosociological Attribute of Plant Species in Site - C of Badoli Forest

\begin{tabular}{l|llccccc} 
Species & D & F & A & A/F & MBA & TBA & IVI \\
C. deodara & & & & & & & \\
C. buchanani & .35 & 20 & 1.75 & .08 & 1365.23 & 477.83 & 12.67 \\
E. officinalis & .35 & 15 & 2.33 & .15 & 658.79 & 230.58 & 8.41 \\
F. ausiculata & 2.45 & 50 & 4.90 & .09 & 206.92 & 506.96 & 31.55 \\
M. esculenta & .30 & 15 & 2.0 & .13 & 630.15 & 189.05 & 7.63 \\
P. roxburghii & 2.15 & 60 & 3.58 & .05 & 459.51 & 987.94 & 38.35 \\
Q.floribunda & 1.15 & 40 & 2.88 & .07 & 496.50 & 570.97 & 23.00 \\
Q.leucotrichophora & 5.85 & 90 & 6.50 & .07 & 423.95 & 2480.08 & 83.49 \\
R. arborium & 4.60 & 75 & 6.13 & .08 & 412.41 & 1897.09 & 66.06 \\
TOTAL & 1.85 & 35 & 5.28 & .15 & 459.51 & 850.09 & 28.84 \\
SAPLING & $\mathbf{1 9 . 0 5}$ & $\mathbf{4 0 0}$ & & & & $\mathbf{8 1 9 0 . 5 9}$ & $\mathbf{3 0 0}$ \\
C. deodara & & & & & & & \\
C. buchanani & .15 & 10 & 1.5 & .15 & 71.60 & 10.74 & 11.91 \\
E. officinalis & .15 & 10 & 1.5 & .15 & 25.77 & 3.87 & 8.49 \\
F. ausiculata & .65 & 30 & 2.16 & .07 & 17.90 & 11.63 & 28.46 \\
M. esculenta & .10 & 5 & 2.0 & .400 & 22.99 & 2.29 & 4.79 \\
P. roxburghii & .80 & 35 & 2.29 & .060 & 31.82 & 25.46 & 39.74 \\
Q.floribunda & .55 & 20 & 2.75 & .14 & 35.08 & 19.29 & 26.44 \\
Q.leucotrichophora & 2.8 & 70 & 4.0 & .06 & 28.72 & 80.41 & 11.92 \\
R. arborium & 1.3 & 35 & 3.71 & .11 & 30.25 & 39.33 & 54.05 \\
TOTAL & .25 & 15 & 1.67 & .11 & 31.82 & 7.96 & 14.18 \\
& $\mathbf{6 . 7 5}$ & $\mathbf{2 3 0}$ & & & & $\mathbf{2 0 0 . 9 8}$ & $\mathbf{3 0 0}$ \\
SEEDLING & & & & & & & \\
C. deodara & & & & & & & \\
C. buchanani & .10 & 10 & 1 & .01 & 7.96 & 0.79 & 13.03 \\
E. officinalis & .20 & 10 & 2 & .20 & 2.58 & 0.51 & 12.82 \\
F. ausiculata & .07 & 25 & 2.8 & .11 & 1.61 & 1.13 & 34.93 \\
M. esculenta & .05 & 5 & 1 & .20 & 2.22 & 0.11 & 4.19 \\
P. roxburghii & 1 & 35 & 2.86 & .01 & 3.06 & 3.06 & 61.43 \\
Q.floribunda & .45 & 20 & 2.25 & .11 & 2.87 & 1.29 & 28.86 \\
Q.leucotrichophora & 1.25 & 50 & 2.5 & .05 & 2.58 & 3.23 & 74.75 \\
R. arborium & .85 & 50 & 1.7 & .03 & 1.76 & 1.49 & 52.31 \\
TOTAL & .30 & 15 & 2 & .13 & 1.91 & 0.57 & 17.61 \\
& $\mathbf{4 . 2 7}$ & $\mathbf{2 2 0}$ & & & & $\mathbf{1 2 . 1 8}$ & $\mathbf{3 0 0}$ \\
\hline
\end{tabular}

Table.5 The Distribution Pattern of Vegetation in Different Compartment of Badoli Forest

\begin{tabular}{|c|c|c|c|}
\hline COMPARTMENT & REGULAR & RANDOM & CONTAGIOUS \\
\hline $\begin{array}{ll}\text { A. } & \text { TREE } \\
& \text { SAPLING } \\
& \text { SEEDLING }\end{array}$ & $\begin{array}{l}-\overline{-} \\
7 \% \\
7 \%\end{array}$ & $\begin{array}{ll}20 \% & \\
22 \% & \\
& 13 \%\end{array}$ & $\begin{array}{l}80 \% \\
71 \% \\
80 \%\end{array}$ \\
\hline $\begin{array}{ll}\text { B. } & \text { TREE } \\
& \text { SAPLING } \\
& \text { SEEDLING }\end{array}$ & - & $\begin{array}{c}13 \% \\
- \\
14 \%\end{array}$ & $\begin{array}{l}87 \% \\
100 \% \\
86 \%\end{array}$ \\
\hline $\begin{array}{ll}\text { C. } & \text { TREE } \\
& \text { SAPLING } \\
& \text { SEEDING }\end{array}$ & $\begin{array}{l}11 \% \\
12 \%\end{array}$ & $\begin{array}{l}- \\
- \\
22 \%\end{array}$ & $\begin{array}{l}89 \% \\
100 \% \\
66 \%\end{array}$ \\
\hline
\end{tabular}


Table.6 Species Richness, Diversity, Evenness and Concentration of Dominance (CD) in Different Compartment of Badoli Forest

\begin{tabular}{|c|c|c|c|}
\hline COMPARTMENT & $\begin{array}{c}\text { SPECIES } \\
\text { RICHNESS }\end{array}$ & $\begin{array}{c}\text { SPECIES } \\
\text { DIVERSITY }\end{array}$ & $\begin{array}{l}\text { CONCENTRATION } \\
\text { OF DOMINANCE }\end{array}$ \\
\hline A. TREE & 19 & 2.84 & .154 \\
\hline SAPLING & 14 & 3.06 & .144 \\
\hline SEEDLING & 15 & 3.17 & .141 \\
\hline B. TREE & 15 & 2.73 & .214 \\
\hline SAPLING & 14 & 3.11 & .176 \\
\hline SEEDLING & 14 & 3.09 & .083 \\
\hline \multirow{3}{*}{$\begin{array}{ll}\text { C. } & \text { TREE } \\
& \text { SAPLING } \\
& \text { SEEDLING }\end{array}$} & 9 & 2.62 & .191 \\
\hline & 9 & 2.79 & .268 \\
\hline & 9 & 2.96 & .224 \\
\hline
\end{tabular}

Fig.1 Map and Location of Study Site

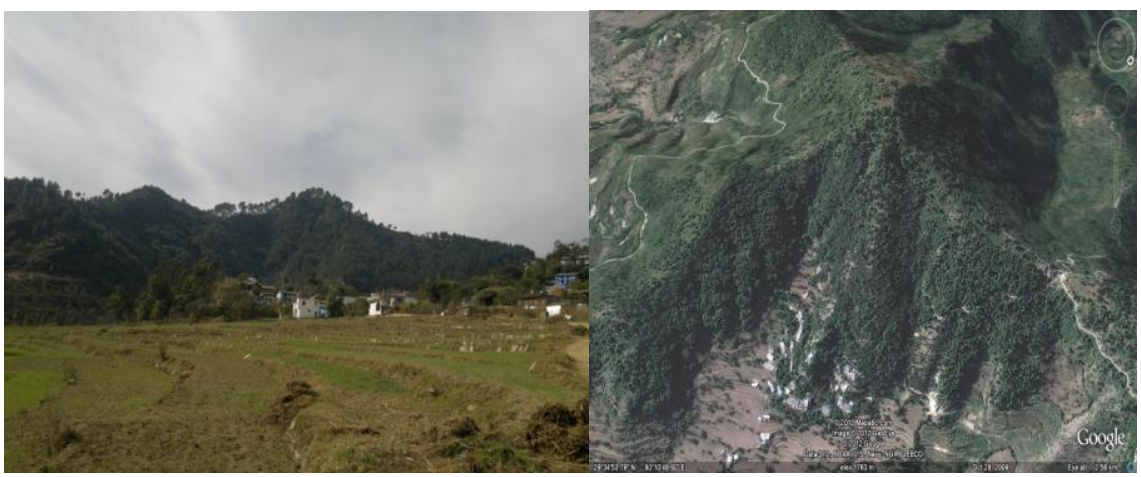

Fig.2 Variation in Species Richness of Tree among the Different Compartment of Badoli Forest

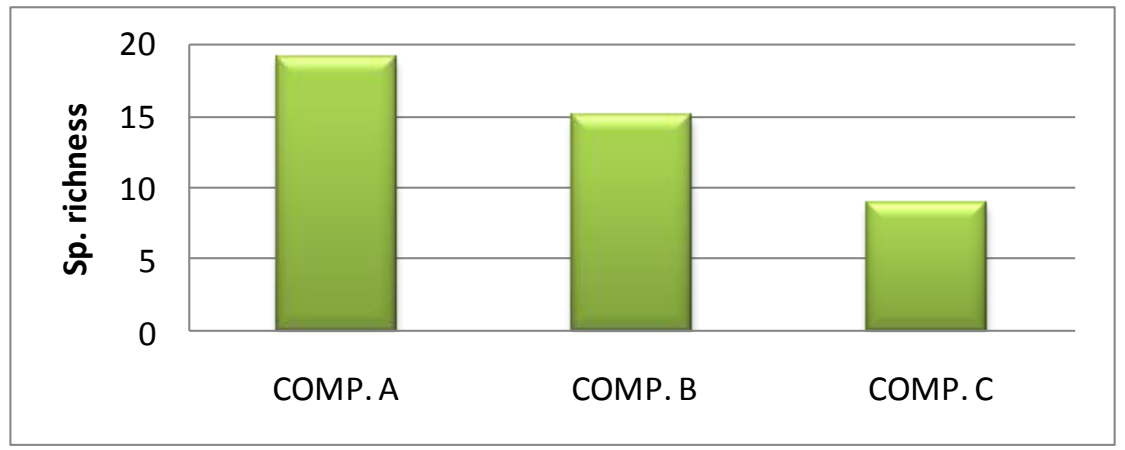

Fig.3 Different Diversity Indices of Trees in Badoli Forest 
The highest tree density has been found to be 8.95 trees $/ 100 \mathrm{~m}^{2}$ for Quercus floribunda, and which was followed by Quercus leucotrichophora, with density $(6.55$ trees $/ 100 \mathrm{~m}^{2}$ ) was found. The density of Quercus floribunda is higher (5.85 trees/ha) in compartment $\mathrm{C}$ than in other compartment. The mean basal area of Quercus floribunda in comp. - C was found to be $423.95 \mathrm{~cm}^{2} /$ tree and IVI 83 . It was observed that in this stand of forest the species richness (9) and the diversity is very low, though in the adjacent forest both are quite high. Quercus leucotricophora has been found to be a sub-dominant species in terms of a density of 4.60 trees $/ \mathrm{cm}^{2}$ in this habitat type. Quercus floribunda and Quercus leucotricophora occupied the dominant and co-dominant tree species in sense of density, MBA and IVI in both the sapling and seedling stratum of $\mathrm{C}$ stand. The structure of the stand types described here is different in regard to the dominance (in terms of density) of different species. The comp. A of Badoli forest has the highest species richness (19) and also exhibits the highest species diversity of 2.84 (Table 5). Species diversity varies widely in different forests. The concentration of dominance (CD) varied between 0.154 and 0.191 (Table $5)$. The highest $C D$ of 0.191 was recorded in compartment $\mathrm{C}$. The high value in stand- $\mathrm{C}$ indicates that the dominance is acquired by a few species only. The low diversity and consequently greater concentration of dominance could be due to a lower rate of evolution and diversification of the communities (Simpson, 1964; Ralhan et al., 1982). The growth of saplings and seedling in all the habitat types is high 3.06 and 3.17 in compartment $\mathrm{A}$ with concentration of dominance .144 and .141 respectively is due to its ruder nature (Singh \& Singh, 1987).While minimum concentration of dominance of sapling and seedling 2.79 and 2.96 was reported in compartment $\mathrm{C}$.

\section{References}

Curtis, J.T. \&Cottom, G. 1956. Plant ecology workbook. Laboratory field reference manual. Burgess publ. co., Minnesota. 193pp.

Curtis, J.T., McIntosh, R.P. 1951. An upland forest continuum in prairie- forest Border region of Wisconsin. Ecology, 32: 47696.

Kershaw, K.R, 1973. Quantitative and dynamic plant ecology, Edward Arnold ltd., London .308 pp.

Knight, D.H. $1975 . \quad$ A phytosociologicalanalysis of species rich tropicalforest on Barroclorada Island.Panama. Ecol. Mongr., 45: 259284.

Misra, R., 1968. Ecology workbook, Oxford and IBH publ. co. Calcutta. 244pp

Phillips, E.A. 1959. Method of vegetation study. Henry Holt and Co. Inc., NewYork.

Ralhan, P.K., Saxena, A.K. and Singh, J.S.1982. Analysis of forest vegetation at and around Nainital in Kumaun Himalaya Proc. Indian Nat. Sci. Acad.,48B:122-138.

Shannon, C.E., Weaver, W.E. 1963. The Mathematical theory of communication. University of IIIinois Press, Urbana, USA. 117 Pp.

Simpson, E.H. 1949. Measurement of diversity. Nature, 163: 688.

Singh J S, Singh S P.1992 Forest of Himalaya, Structure, Functioning and impact of Man. Gyanodaya Prakashan,; Nainital, India.

Singh, J.S. and Singh, 1987.S.P. Forest vegetation of Himalaya. The Botanical Review, 53: 80-193.

Saxena, A.K. and Singh, J.S. 1984. Tree population structure of certain Himalayan forest associations and implications concerning future composition. Vegetatio, 58: 61-69 
Whitford, P.B. 1949. Distribution of woodland plants in relation to succession and clonal growth. Ecology, 30: 199288.

Whittaker, R.H. 1965. Dominance anddiversity in land plant communities. Science, 147: 250260

Whittaker, R.H. and Levin, S.A. (1977).The role of mosaic phenomena in mosaic communities. Theoretical Population Biology, 12: 117-139.

\section{How to cite this article:}

Anjali Bhatt and N.S. Bankoti. 2016. Analysis of forest vegetation in Pithoragarh Kumaun Himalayas, Uttrakhand, India. Int.J.Curr.Microbiol.App.Sci. 5(2): 784-793. doi: http://dx.doi.org/10.20546/ijcmas.2016.502.089 